\title{
Madanidinium loirii gen. et sp. nov. (Dinophyceae), a new marine benthic dinoflagellate from Martinique Island, Eastern Caribbean
}

\author{
Nicolas Chomérat and Gwenaël Bilien
}

IFREMER, LER Bretagne-Occidentale, Station de biologie marine, Place de la Croix, 29900 Concarneau, France

*: Corresponding author : Nicolas Chomérat, email address : Nicolas.Chomerat@ifremer.fr

\begin{abstract}
:
A new benthic phototrophic dinoflagellate is described from sediments of a tropical marine cove at Martinique Island and its micromorphology is studied by means of light and electron microscopy. The cell contains small golden-brown chloroplasts and the oval nucleus is posterior. It is laterally compressed, almost circular in shape when viewed laterally. It consists of a small epitheca tilted toward the right lateral side and a larger hypotheca. In the left view, the cingulum is more anterior and the epitheca is reduced. The cingulum is displaced and left-handed. This organism is peculiar in having no apical pore and its thecal plate arrangement is $2^{\prime} 1$ a $7 "$ " $5 c 3 s 5^{\prime \prime \prime} 1^{\prime \prime \prime \prime}$. The plates are smooth with small groups of pores scattered on their surface. An area with $60-80$ densely arranged pores is found near the centre of the 2"' plate, on the left lateral side. Morphologically, these features are different from all other laterally compressed benthic genera. In addition, molecular genetic sequences of SSU and partial LSU form a distinct and well-supported clade among dinoflagellates and support the erection of a new genus. However, molecular phylogenies inferred from ribosomal genes failed to confirm any clear relationship with other benthic taxa and affinity with other laterally compressed dinoflagellates has not been demonstrated. Hence, the taxonomic affinity of Madanidinium loirii with a defined order and family is unclear at the moment.
\end{abstract}

Keywords: benthic ; Caribbean ; Dinophyceae ; Martinique ; Morphology ; Phylogeny ; rDNA ; SEM ; taxonomy 


\section{Introduction}

47 Since they have been discovered and studied by E.C. Herdman (1921, 1922, 1924a, b), benthic dinoflagellates stayed poorly studied for several decades (Balech, 1956; Dragesco, 1965). They gained a new interest for scientists when the epiphytic species producing maitotoxin and ciguatoxin, namely Gambierdiscus toxicus was associated with ciguatera disease in the tropical Pacific (Adachi \& Fukuyo, 1979; Taylor, 1979). Then, several other benthic taxa were found to be harmful and involved in the complex mechanism of ciguatera (Bomber \& Aikman, 1989; Litaker et al., 2010). Because of this potential toxicity, several taxonomic studies were subsequently realized in the tropical regions (Fukuyo, 1981; Besada et al., 1982; Berland et al., 1992; Grzebyk et al., 1994; Chinain et al., 1999) but also in temperate areas worldwide (e.g. Horiguchi \& Chihara, 1983; Saunders \& Dodge, 1984; Larsen, 1985; Hoppenrath, 2000b; Aligizaki \& Nikolaidis, 2006; Murray, 2009; Chomérat et al., 2010b; Fraga et al., 2011). caused health problems for many years (Bagnis, 1981; Olsen et al., 1984; Tosteson, 2004; Tester et al., 2010), studies on benthic dinoflagellates were mostly focused on epiphytic species responsible for this disease, in order to better understand their distribution and assess the associated risk. Several investigations were made in the northern and eastern parts of the basin (Ballantine et al., 1985; Taylor, 1985; Ballantine et al., 1988; Litaker et al., 2010). On the western side, other studies have later been realized on Belizean coast (e.g. Faust \& Gulledge, 2002; Faust, 2009), and around the

67 Mexican and Cuban coasts (Hernández-Becerril \& Almazán Becerril, 2004; Delgado et al., 2006). Comparatively, southern Caribbean sea has been only scarcely investigated by Grzebyk et al. (1998) who collected samples in a Panamian island and Rodriguez et 
al. (2010) who made a survey in San Andrés Island (Caribbean Colombia). In French Antilles (also known as French West Indies) where ciguatera intoxications have been recurrently documented (Olsen et al., 1984; Vernoux, 1988; Pottier et al., 2001; Rosine et al., 2008; Tester et al., 2010), only a few surveys have been undertaken to check the presence and identify toxigenic species (Besada et al., 1982; Taylor, 1985; Litaker et al., 2010).

Harmful species apart, taxonomic studies focused on the diversity of benthic dinoflagellates are relatively scarce in the Caribbean. The first major contribution was made by Carlson (1984) who collected samples in several places in Virgin Islands and identified 38 benthic taxa. Then, M. A. Faust investigated extensively the western coast and published a remarkable series of papers with descriptions or reinvestigations of taxa from coral-reefs mangrove embayments in Belize (Faust, 1990, 1993a, b, c, 1994, 1996; Faust et al., 1996; 2008). In the course of her study, she described the very atypical and intriguing genus Plagiodinium (Faust \& Balech, 1993), which has been then found very infrequently in other areas (M. Saburova, pers. comm.) and still needs further investigation. Indeed, most of these taxa are known only from their morphology, and it would now be of a great importance to complement their knowledge with DNA sequences to better understand their phylogenetic position within dinoflagellates lineages (Hoppenrath et al., 2013).

Since no taxonomic survey has been realised to date in French Antilles, we undertook to assess the diversity of benthic dinoflagellates in Martinique Island from occasional samples. During our study, we encountered a very atypical and interesting taxon, which is distinct from any armoured dinoflagellate genus hitherto described. Cells are strongly flattened laterally, and thecal plates are delicate and arranged with a 
94 unique pattern. In the present paper, we aim to describe its morphology using light and scanning electron microscopy, and attempt to establish its phylogenetic position among other dinoflagellates using molecular data from environmental samples and clonal cultures.

\section{Material and methods}

\section{Sampling and cultivation}

Martinique Island is a French volcanic island of the Lesser Antilles archipelago, located in the eastern part of the Caribbean Sea (Fig. 1). It is about $70 \mathrm{~km}$ long and $30 \mathrm{~km}$ wide. Samples of upper sediments were collected by snorkelling (1 to $3 \mathrm{~m}$ below the surface of water) at Anse Dufour (coordinates $14^{\circ} 31.538^{\prime} \mathrm{N}, 61^{\circ} 05.446^{\prime} \mathrm{W}$ ), a cove located on the Caribbean side of the island (Fig. 1), the 16 March 2010, and 22, 26, 30 March and 6 April 2013. All samples of March 2010 and March 2013 were immediately preserved with acidic Lugol's solution ( $\sim 5 \%$ final concentration) and stored in the dark at $4{ }^{\circ} \mathrm{C}$ before further examination. The 6 April 2013, aliquots were fixed and stored in the same conditions, and aliquots were kept fresh for algal isolation and cultivation. Immediately after collection, they were carefully packed to limit thermal variations in the baggage compartment and transferred to Ifremer laboratory in Concarneau (mainland France) by plane and train. Because of travel duration, the isolation of living cells was carried out two days after sampling (8 April).

For cultivation, single cells from the live sediment subsamples were identified and isolated with a micropipette under an IX41 (Olympus, Tokyo) inverted microscope. Then, they were rinsed in several drops of seawater and placed in 96-well culture plates containing seawater and medium. After some divisions, each clonal strain was 
118 transferred to culture plates with increasing well volume. Several cultures were

119 established but only two were kept and grown in $50 \mathrm{ml}$ culture flasks. The strain IFR-

120 MLO-01M was grown in K medium (Keller et al., 1987) while the second strain IFR-

121 MLO-02M was grown in f/2 medium (Guillard \& Ryther, 1962; Andersen et al., 2005).

122 Both strains were maintained in a growth chamber set up at $22 \pm 1.0{ }^{\circ} \mathrm{C}$ and $12: 12$ light

123 : dark illumination cycle with $\sim 50 \mu \mathrm{mol}$ photons $\mathrm{m}^{-2} \mathrm{~s}^{-1}$ provided by white fluorescent 124 tubes.

125

\section{Observations}

127 LM

128 Observations in light microscopy were performed on isolated cells put on standard slide 129 with a coverslip, using a BX41 (Olympus, Tokyo) upright microscope. It was equipped 130 with brightfield, differential interference optics, epifluorescence filter sets U-MWU2 for

131 DAPI stain (excitation: BP330-385; beamsplitter: DM400; emission: BA 420) and U-

132 MWIB2 for chlorophyll autofluorescence (excitation: BP460-490; beamsplitter:

133 DM505; emission: BA510IF), an Osram mercury short arc HBO 100W lamp as the

134 light source for epifluorescence, and a DP72 (Olympus, Tokyo) color digital camera.

135 To visualize the nuclei, some cells from the culture were isolated and fixed with $2 \%$

136 glutaraldehyde for $10-20 \mathrm{~min}$ at $4{ }^{\circ} \mathrm{C}$, and then stained with 4 , 6 -diamidino-2-

137 phenylindole (DAPI) according to Chomérat et al. (2012). In addition, thecal plates

138 were observed using Calcofluor White M2R (Sigma Aldrich) as fluorescent dye.

140 Scanning electron microscopy 
141 Cells from the cultures were obtained after a vigorous shaking of the flask, and then

142 fixed with $2 \%$ formaldehyde. Then, the specimens were processed according to the

143 methods described in Couté (2002) and Chomérat \& Couté (2008). They were

144 dehydrated and critical point dried, and then they were observed with a Quanta 200

145 (FEI, Eindhoven, The Netherlands) scanning electron microscope with an acceleration

146 voltage of $5 \mathrm{kV}$ and a secondary electrons detector.

147 Cells were measured from SEM digital micrographs using ImageJ software (Rasband,

148 1997-2006). SEM images were presented on a uniform background using Adobe

149 Photoshop CS5 (v. 12.1, Adobe Systems).

150

151

DNA amplification and sequencing

152 Single cells from the fixed sediment sample of the 16 March 2010 were isolated with a capillary pipette under the IX41 inverted microscope. They were rinsed in several drops

154 of distilled water and then placed in a $0.2 \mathrm{~mL}$ PCR tube containing $5 \mu \mathrm{l}$ of distilled

155 water. Living cells from the two cultures were isolated similarly and 1 to 5 cells were

156 placed into PCR tubes. All tubes were stored at $-20{ }^{\circ} \mathrm{C}$ prior to analysis. For PCR, tubes

157 were thawed and processed as described previously in Chomérat et al. (2010b).

158

159

Molecular analysis and phylogeny

160 The SSU and LSU sequences obtained were aligned with other dinoflagellates

161 sequences and Perkinsus marinus (perkinsoid, Alveolate) as external group, using

162 MAFFT software version 7 (Katoh \& Standley, 2013) with selection of the Q-INS-i

163 algorithm which considers the secondary structure for the alignment. This step was

164 followed by refinement by eye with MEGA software version 5.2.1 (Tamura et al., 
165 2011). For SSU a dataset of 77 taxa and 1691 aligned positions has been used. For LSU,

166 a matrix of 49 taxa and 860 positions was used. Ambiguous parts of the alignment

167 (including the D2 domain) were excluded from the analysis using gblocks software 168 version $0.91 \mathrm{~b}$, with less stringent parameters. Genbank accession numbers of all 169 sequences used are available in the supplementary material.

170 For each data set, evolutionary models were examined using maximum 171 likelihood (ML) and Bayesian Inference analysis (BI). The evolutionary model was 172 selected using jModelTest version 0.1.1 (Posada, 2008). According to Akaike 173 information criterion (AIC) and Bayesian information criterion (BIC), a general time

174 reversible (GTR) model with a gamma correction $(\Gamma)$ for among-site rate variation and 175 invariant sites was chosen for the SSU dataset while a Tamura-Nei model with no 176 invariant sites was chosen for the LSU dataset.

177 Maximum likelihood analyses were performed using PhyML version 3.0

178 (Guindon et al., 2010), and Bayesian analyses were run using Mr Bayes version 3.1.2

179 (Ronquist \& Huelsenbeck, 2003). Bootstrap analysis (1000 pseudoreplicates) was used 180 to assess the relative robustness of branches of the ML tree. Initial Bayesian analyses 181 were run with a GTR model (nst=6) with rates set to invgamma (gamma for LSU 182 dataset). Each analysis was performed using four Markov chains (MCMC), with two 183 millions cycles for each chain. Trees were saved every 100 cycles and the first 2000 184 trees were discarded. Therefore, a majority-rule consensus tree was created from the 185 remaining 18000 trees in order to examine the posterior probabilities of each clade.

186 The consensus trees were edited using MEGA 5 software. The best ML 187 phylograms are shown with robustness values for each node (ML/BI). 
Madanidinium loirii gen. et sp. nov. Chomérat (Figs 2-28)

DiAGNOSIS GENERICO-SPECIFICA (art. 38.5, McNeill et al., 2012)

191 Genus repositum in Dinophyta ; in incertum ordinem et incertam familiam ; solitarium ;

192 marinum ; cum theca et in arena vivens. Cellulae fere circulares in latere visu valdeque

193 compressae a latere in ventrali visu. Longitudo : 25.2-31.0 $\mu \mathrm{m}$; latitudo : 16.7-18.7 $\mu \mathrm{m}$

194 ; dorsoventralis altitudo : 22.1-28.8 $\mu \mathrm{m}$. Epitheca inclinata et deminuta ; altior in

195 dextero aspectu. Porus apicalis absens. Cingulum cellulam perfecte cingens et

196 descendens ; transversus in sinistro visu et obliquus in dextero visu. Hypotheca major.

197 Thecae laminarum tabulatio : $2^{\prime} 1$ a 7" 5c 3s 5"' $1^{\prime \prime \prime \prime}$. Laminae thecae laeves cum poris in

198 parvo numero agreggatis aequabiliterque dispersi in tota theca. Lamina $2^{\prime \prime \prime}$ cum parva

199 regione praebenti poros dense compressos. Parvi chloroplasti numerosi. Nucleus ovalis

200 in posteriore cellulae parte positus.

201

202 ETYMOLOGY: the genus is named after Madanina, the ancient local name of Martinique

203 Island (du Tertre, 1667-1671; Daney de Marcillac, 1846) and-dinium suffix for

204 Dinophyceae. The specific epithet loirii commemorates Maurice Loir (French diatomist) who collected many samples from Martinique Island, and who kindly offered

206 to the authors those used in the present study.

208 TYPE SPECIES: Madanidinium loirii

209 HoLOTYPE: Fig. 11 (cell from the culture IFR-MLO-02M, SEM stub IFR-13H6 has

210 been deposited to the Centre of Excellence for Dinophytes Taxonomy (CEDiT) with the 211 accession reference CEDiT2013H22). 
212 IsOTYPES: Figs 12-13, fixed culture CEDIT2013I23

213 TyPe LOCALITY: Anse Dufour $\left(14^{\circ} 31.538^{\prime} \mathrm{N}, 61^{\circ} 05.446^{\prime} \mathrm{W}\right)$, Martinique Island, eastern

214 Caribbean Sea.

215 DNA SEQUENCE INFORMATION: Sequences have been deposited in Genbank under

216 accession numbers KF751599, KF751600, KF751601, KF751602, KF751603 and

$217 \quad$ KF751604.

218

219 The cells are laterally flattened, with their depth (i.e. dorso-ventral width) larger than

220 lateral width. Hence, they are mostly observed in lateral view and their shape is almost

221 circular (Figs 2-3, 5-6). They are 25.2-31.0 $\mu \mathrm{m}$ long (mean $28.9 \mu \mathrm{m}$, s.d. $1.4 \mu \mathrm{m}$,

$222 n=16$ ), 22.1-28.8 $\mu \mathrm{m}$ deep (mean $25.9 \mu \mathrm{m}$, s.d. $1.8 \mu \mathrm{m}, n=16)$ and 16.7-18.7 $\mu \mathrm{m}$ wide

$223(n=2)$. The length to depth ratio varies from 1.05 to 1.21 (mean 1.12, S.D. 0.05, $n=16$ ).

224 The cingulum is anterior and descending (left-handed) (Figs 4, 11, 13). Seen from the

225 left side (Figs 3, 12), it is straight, anterior, and the epitheca is very small, emerging of

226 1.7-2.7 $\mu \mathrm{m}(n=5)$ above the cingulum. In contrast, in the right lateral view (Figs 2, 11),

227 the epitheca is higher $(4.1-7.6 \mu \mathrm{m}, n=7)$, and the cingulum is conspicuously oblique,

228 descending towards the ventral area (Figs 11, 24, 27).

229 Cells contain small yellow-brown chloroplasts. The oval nucleus is located

230 posteriorly (Figs 5, 7, 24). Some cells have a large pusule located on the anterior ventral

231 side, near the sulcal area (Figs 3, 24).

232 The thecal plate pattern is $2^{\prime} 1 \mathrm{a} 77^{\prime \prime} 5 \mathrm{c} 3 \mathrm{~s} 5^{\prime \prime \prime} 1^{\prime \prime \prime \prime}$. The epitheca comprises 10

233 plates and does not have an apical pore (Figs 16, 26). Since the application of the

234 Kofoid nomenclature of thecal plates was not straightforward, we decided that the

235 apical plates were those in contact with the apex (geometrically speaking) of the cell 
and the unique plate actually not in contact with the apex and the cingulum is considered as an intercalary plate. In apical view, the epitheca is roughly pear-shaped, and tapers ventrally (Fig. 16). Plates are arranged asymmetrically and those on the right side are higher than those inserted on the left side (Figs 16-18, 26). The $1^{\prime}$ and $2^{\prime}$ plates are medium-sized, pentagonal and located at the apex of the slightly dome-shaped epitheca (Figs 16-17). The 1" plate is elongated, five sided and located ventrally (Figs $16,19)$. The $2 "$ and $3 "$ plates are pentagonal and border the left side of the epitheca (Figs 16, 18). The 4" and 5" plates are very small, rectangular, four-sided, and located on the dorsal side of the epitheca (Figs 17, 20). The 6" plate which is the largest of the epitheca, is six-sided (Figs 16-17). The 7" plate is roughly trapezoidal and four-sided (Figs 16, 19), although it has a very short contact with the Sd plate ventrally (Figs 9, 10, 19). The unique intercalary plate $1 \mathrm{a}$ is pentagonal and in line with the two apical plates, but it is located more dorsally (Figs 16, 18, 20). unequal in size (Figs 16-18). The $\mathrm{c}_{2}$ plate is large and runs along the left side of the theca, with its distal end facing the suture $2^{\prime \prime \prime} / 3^{\prime \prime \prime}$ on the hypotheca (Fig. 12). The $c_{3}$ plate is small and located dorsally, and is running along the width of the $3^{\prime \prime \prime}$ plate (Fig. 20). The sulcus is moderately long, and slightly oblique with respect to the longitudinal axis

254 of the cell (Fig. 13). In SEM, we partially observed the flagellar pore, which is 255 elongated oval in shape and located ventrally (Fig. 19). It is bordered by three major 256 sulcal plates Sa, Sd, and Sp (Figs 13, 19). Our observations of the sulcus using epifluorescence microscopy on several specimens confirm that the sulcus is composed of three plates (Figs 9, 10). The Sa plate is hook-shaped and in contact with the $\mathrm{c}_{1}$ plate. 
259 The Sd plate forms the end of the cingulum and connects the epitheca. The Sp plate is

260 the largest of sulcal plates, and is posteriorly pointed (Figs 9-10).

261 The hypotheca is formed of 6 major plates. The first postcingular plate $1^{\prime \prime \prime}$ is

262 ventral and folds in order to form a flange covering the left side of the sulcus (Figs 11,

263 13). The $2^{\prime \prime \prime}$ plate which is the largest of the hypotheca, is trapezoidal and four-sided,

264 covering most of the left lateral side (Fig. 12). The $3^{\prime \prime \prime}$ plate is rectangular and is located

265 on the dorsal side of the hypotheca (Fig. 14). The 4"' plate is large and four sided (Fig.

266 11). The $5^{\prime \prime \prime}$ plate is the smallest of postcingular plates and contacts six plates, namely

$26711^{\prime \prime \prime}, 4^{\prime \prime \prime}, 1^{\prime \prime \prime \prime}, \mathrm{c}_{5}, \mathrm{Sd}$ and Sp (Fig. 13). The antapical plate 1"'" is pentagonal and elongated

268 (Fig. 15).

269 Thecal plates are thin, delicate, and smooth. They are covered by small groups

270 of pores, and some isolated pores (0.1-0.2 $\mu \mathrm{m}$ in diameter) (Fig. 21). On the large

271 lateral plate $2^{\prime \prime \prime}$, an area of closely arranged pores $(68-86$ in number; $n=4)$ of $0.08-0.1$

$272 \mu \mathrm{m}$ in diameter is present nearly in the centre (Figs 12, 22-23). This area is variable in

273 shape, being circular to elongated (Figs 22-23).

274 In culture, cells of $M$. loirii are almost always attached to the bottom of the

275 container, and swimming cells are observed occasionally. The cells are strongly

276 adherent to the substrate by their lateral sides and they appear almost always in lateral

277 views. However, no particular structures such as stalks have been observed.

278

279 Molecular phylogeny

280 The results of the SSU and LSU phylogenetic analyses show that the sequences

281 acquired from cultures and environmental specimens group together within a well

282 supported clade (Figs 29, 30). In the phylogeny inferred from SSU, the position of 
283 Madanidinium clade is not supported and no clear relationships with other genera

284 emerge (Fig. 29). In the LSU analysis, Madanidinium appears as a sister-clade to

285 Adenoides eludens (Fig. 30), albeit without support (bootstrap value of 51 in ML and

286 posterior probability of 0.90 in BI). In addition, the clade formed by Madanidinium and

287 Adenoides forms a sister group with Prorocentrum species but without support.

288

289 Discussion

290 Morphologically, Madanidinium has features closely related to other strongly laterally

291 compressed sand-dwelling genera with a reduced epitheca like Plagiodinium,

292 Planodinium, Sabulodinium, Cabra, and Pileidinium (Table 1) but also some

293 Thecadinium species (Hoppenrath 2000a, Yoshimatsu et al., 2006). In addition, a

294 morphological resemblance can be found with the genus Sinophysis Nie et Wang

295 (Dinophysales), that is also strongly laterally compressed and possesses a reduced-

296 epitheca (Hoppenrath 2000b), but the thecal plate organization of Madanidinium is not

297 of the dinophysoid type and no further comparison is possible. In Plagiodinium

298 belizeanum, the epitheca is atypical, very small and slightly inclined to the ventral side

299 (Faust \& Balech, 1993), which differs from M. loirii. The left-handed displacement of

300 the cingulum in M. loirii is peculiar and reminds that of Thecadinium yashimaense

301 (Bolch \& Campbell, 2004; Hoppenrath et al., 2004; Yoshimatsu et al., 2004;

302 Hoppenrath et al., 2005), but also the planktonic taxa Thecadiniopsis tasmanica and

303 Pseudothecadinium campbellii (Croome et al., 1987; Hoppenrath \& Selina, 2006). This

304 is the reverse situation in the benthic genus Cabra where the epitheca is higher on the

305 left side than on the right lateral side. When seen in the left lateral view, M. loirii

306 outline is very similar to that of Sabulodinium, because the epitheca is almost not visible 
307 and the cingulum is short and very anterior. However, in Sabulodinium, the cingulum is 308 not displaced, as well as in Planodinium (Saunders \& Dodge, 1984; Hoppenrath et al.,

309 2007). And in contrast with Pileidinium, the cingulum is complete in Madanidinium.

310 Hence, owing to its peculiar overall morphology and position of the cingulum, $M$. loirii

311 can be easily distinguished from most other benthic genera with the light microscope.

312 Concerning the plate pattern, Madanidinium is also very atypical. The number

313 and arrangement of epithecal plates is the major discrepancy with other genera (Table

314 1). The absence of an apical pore on the epitheca is a striking and uncommon feature

315 which has been reported to date only in Planodinium striatum (Saunders \& Dodge,

316 1984) and a few Thecadinium species, as shown first by Hoppenrath (2000a) and then

317 by Yoshimatsu et al. (2004). Comparatively, in Plagiodinium belizeanum, the authors

318 reported an unusual, minute plate provisionally named Po, which has been seen only at

319 high magnification with the light microscope (Faust \& Balech, 1993). Unfortunately, it

320 has not been studied in SEM and no detailed information about this pore is available. In

321 Pileidinium ciceropse, a simple circular pore has been found on the epitheca (Tamura \&

322 Horiguchi, 2005) and it is considered as homologue of the apical pore present in other

323 taxa. Interestingly, the asymmetric epitheca of Madanidinium with precingular plates

324 larger on the right side and smaller plates on the left side is an unusual character not

325 found in other genera with a displaced cingulum such as Cabra or Thecadiniopsis.

326 The presence of five cingular plates in Madanidinium is a feature found also in

327 in Plagiodinium, Sabulodinium, Thecadiniopsis and Thecadinium. Croome et al. (1987)

328 emphasized that this is a character similar with freshwater peridinioids, while most of

329 gonyaulacoids have six plates. The reduced number and very simple arrangement of the

330 sulcus of Madanidinium is remarkable and to date it is the minimum number of sulcal 
331 plates observed in a benthic genus. In other taxa, four or more sulcal plates have been

332 described. Nevertheless, although we have used epifluorescence microscopy and plate

333 staining, it cannot be excluded that some very small platelets have been overlooked in

334 our study, since the sulcus is a difficult part to study. In addition, since the 1" plate

335 seems to have a short contact with the flagellar pore, it could be alternatively interpreted

336 as a fourth sulcal ( $\mathrm{Sa}$ ) plate. However, as it is not part of the furrow and is actually

337 completely in the epitheca, we considered that it fits better with the definition of a

338 precingular plate. Moreover, the plate that we interpreted as Sa is hook-shaped, as in

339 some gonyaulacoid genera like Alexandrium.

340 The arrangement of plates on the hypotheca of $M$. loirii is not distinctive and

341 many benthic dinoflagellates like Cabra, Plagiodinium, Sabulodinium, Pileidinium

342 (Table 1), Thecadinium pro parte and the planktonic genera Thecadiniopsis and

343 Pseudothecadinium have a similar pattern of five postcingular and one antapical plate.

344 However, the presence of an area of densely arranged pores near the centre of the $2^{\prime \prime \prime}$

345 plate on the left lateral side of the hypotheca is a very uncommon feature among the

346 genera (Table 1). An area of grouped pores (or deep areolae) has been reported in Cabra

347 and some other benthic genera such as Rhinodinium, Roscoffia and in some benthic

348 Prorocentrum species. However this area is antapical and located on the $1^{\prime \prime \prime \prime}$ plate in

349 Cabra, Rhinodinium and Roscoffia (Hoppenrath \& Elbrächter, 1998; Murray et al.,

350 2006; Chomérat et al., 2010a), which differs from Madanidinium where it is lateral as in

351 Prorocentrum species. In Prorocentrum panamense and P. pseudopanamense, a

352 roundish depression with a sieve-like bottom is present on the posterior dorsal side of

353 the right lateral plate (Hoppenrath et al., 2013) while in P. glenanicum, a group of

354 closely arranged pores, very similar to that observed in $M$. loirii, is found just above the 
centre of the right lateral plate (Chomérat et al., 2011). To date, the role of these

structures has not been ascertained, but from observations of a live culture of $P$.

panamense, it seems that cells can extrude mucous from the pores of this area, and attach to the subtrate (M. Saburova, pers. comm.). Such fixation can be very efficient, and this can explain the strong adherence of cells of $M$. loirii in culture flasks. This is

360 likely an adaptation to the benthic way of life to resist to water flow but further ultrastructural studies are required to confirm this hypothesis.

364 Tamura \& Horiguchi, 2005). Interestingly, these two genera are from tropical areas, like

365 Madanidinium. Among Thecadinium species, the type species T. kofoidii has

366 chloroplasts (Hoppenrath, 2000a) and T. yashimaense and T. arenarium are

367 phototrophic (or mixotrophic), as well as Pseudothecadinium (Hoppenrath \& Selina,

368 2006). In contrast, the genera Cabra, Planodinium, Sabulodinium and most

369 Thecadinium species are colourless and strictly heterotrophic (Saunders \& Dodge, 1984;

370 Chomérat et al., 2010a).

As a consequence, morphological features of Madanidinium are different enough from all described genera and justify the establishment of a new genus.

\section{Molecular phylogeny}

375 Molecular data support that Madanidinium loirii corresponds to a new dinoflagellate

376 taxon, since its SSU and LSU sequences diverge from all other known genera.

377 However, as previously shown by several authors, the resolution and support of deeper

378 branches in the phylogenies inferred from ribosomal genes is inexistent or very low, and 
no clear relationship between Madanidinium and other taxa can be found from our analyses. With SSU, the position of this new genus is not stable in the trees, which indicates that this ribosomal gene lacks a good phylogenetic signal which would allow to place it within a higher taxonomic rank (family, order). This problem has already pointed out with several other 'unusual' and monotypic genera of benthic dinoflagellates (Tamura \& Horiguchi, 2005; Hoppenrath et al., 2007; Yamada et al., 2013). Moreover, no relationship was found with any of the morphologically related taxa with a lateral compression for which SSU rDNA sequences are available, such as Sabulodinium, Pileidinium and Thecadinium. Although the position of Sabulodinium and Pileidinium is uncertain in the SSU tree due to the lack of support, they are widely divergent from Madanidinium. From LSU, there is an indication that Madanidinium could be related to Adenoides eludens, another benthic and phototrophic genus, but this is almost unsupported. Morphologically, Adenoides is also compressed laterally, but less than M. loirii, and no similarities in the thecal plate arrangement can be found

393 between these two genera. Thus, the phylogenetic relationship result should be treated

394 with caution because this affinity (not supported) has not been observed in the SSU

395 phylogeny although the sequence of this species was included in the tree. Moreover,

396 there are almost no LSU sequences of the morphologically related taxa compressed

397 laterally available in Genbank, which can bias our analyses. The dataset should be

398 improved with the addition of more taxa. As a consequence, the evolution of benthic

399 and laterally compressed dinoflagellates is still unclear. It is not yet possible to infer

400 whether these genera derived from a common benthic ancestor or if they resulted from a

401 convergent evolution of similar traits well adapted to the benthic life. Hence, a

402 considerable work of sequence acquisition remains to be done for benthic 
403 dinoflagellates, and it is absolutely necessary in order to get a better understanding of

404 the evolution within this very diverse and complex group of protists. This task is

405 rendered difficult by the rarity of these organisms and the difficulty to keep them in

406 cultures. In case of phototrophic taxa, as with Madanidinium, the use of strains in

407 culture can allow extensive ultrastructural, genetic and biochemical studies, which

408 represents a great opportunity to increase the knowledge and understanding of the

409 biology of benthic dinoflagellates.

410

\section{Acknowledgments}

412 The authors wish to thank Mrs E. Nézan for valuable advice and comments on the

413 manuscript, Mr N. Gayet for preparing the samples and use of SEM, Mrs K. Chèze for

414 DNA sequencing and Mrs M. Bouildé for providing useful literature. This work was

415 supported by the Contrat de projet État-Région (PIDETOX) and is a contribution to the

416 Brittany Culture Collection project (Souchothèque de Bretagne).

417

418

419 References

420 ADACHI, R., FUKUYO, Y. (1979). The thecal structure of a marine toxic dinoflagellate

421 Gambierdiscus toxicus gen. et sp. nov. collected in a ciguatera-endemic area. Bulletin of 422 the Japanese Society of Scientific Fisheries 45(1): 67-71.

423 AligiZaKi, K., NiKOlaidis, G. (2006). The presence of the potentially toxic genera

424 Ostreopsis and Coolia (Dinophyceae) in the North Aegean Sea, Greece. Harmful Algae $425 \quad 5(6): 717-730$. 
427 A - Recipes for freshwater and seawater media. In Algal culturing techniques (R. A.

428 ANDERSEN editor), pp. 429-538. Elesevier Academic Press, Burlington.

429 BAGNIS, R. (1981). L'ichtyosarcotoxisme de type ciguatera : phénomène complexe de 430 biologie marine et humaine. Oceanologica acta 4(3): 375-387.

431 BALECH, E. (1956). Étude des dinoflagellés du sable de Roscoff. Revue Algologique 432 2(1-2): 29-52.

433 Ballantine, D., L., Tosteson, T. R., Bardales, A. T. (1988). Population dynamics 434 and toxicity of natural populations of benthic dinoflagellates in southwestern Puerto 435 Rico. Journal of Experimental Marine Biology and Ecology 119(3): 201-212.

436 Ballantine, D., L., Bardales, A. T., Tosteson, T. R., Dupont-Durst, H. (1985). 437 Seasonal abundance of Gambierdiscus toxicus and Ostreopsis sp. in coastal waters of 438 Southwest Puerto Rico. In Proc. Fifth International Coral Reef Congress (C. GABRIÉ, B. 439 SalVAT editors), pp. 417-422. MNHN-EPHE, Moorea, Tahiti.

440 Berland, B., GrzebyK, D., Thomassin, B. A. (1992). Benthic dinoflagellates from the 441 coral reef lagoon of Mayotte Island (S-W Indian Ocean); identification, toxicity and 442 preliminary ecophysiological study. Bulletin de la Société de Pathologie Exotique 85: $443 \quad 453-456$.

444 Besada, E. G., Loeblich, L. A., Loeblich, A. R., III (1982). Observations on tropical, 445 benthic dinoflagellates from ciguatera-endemic areas: Coolia, Gambierdiscus and 446 Ostreopsis. Bulletin of Marine Science 32(3): 723-735. 
447 Bolch, C. J., CAMPBELl, C. N. (2004). Morphology and phylogenetic affinities of

448 Thecadinium foveolatum sp. nov. (Dinophyceae: Thecadiniaceae), a new marine benthic

449 dinoflagellate from the West of Scotland. European Journal of Phycology 39: 351-360.

450 Bomber, J. W., Aikman, K. E. (1989). The ciguatera dinoflagellates. Biological

451 Oceanography 6: 291-311.

452 CARLSON, R. D. (1984). The distribution, periodicity, and culture of benthic/epiphytic

453 dinoflagellates in a ciguatera endemic region of the Caribbean. $\mathrm{PhD}$ thesis. Southern

454 Illinois University, Carbondale. 308 p.

455 Chinain, M., FAust, M. A., PauillaC, S. (1999). Morphology and molecular analyses

456 of three toxic species of Gambierdiscus (Dinophyceae): G. pacificus, sp. nov., G.

457 australes, sp. nov., and G. polynesiensis, sp. nov. Journal of Phycology 35: 1282-1296.

458 Chomérat, N., Couté, A. (2008). Protoperidinium bolmonense sp. nov. (Peridiniales, 459 Dinophyceae), a small dinoflagellate from a brackish hypereutrophic lagoon (South of 460 France). Phycologia 47(4): 392-403.

461 ChOmÉRAT, N., Couté, A., NÉZAn, E. (2010a). Further investigations on the sand462 dwelling genus Cabra (Dinophyceae, Peridiniales) in South Brittany (northwestern 463 France), including the description of $C$. aremorica sp. nov. Marine Biodiversity 40: 464 131-142.

465 Chomérat, N., Sellos, D. Y., Zentz, F., NÉZAn, E. (2010b). Morphology and 466 molecular phylogeny of Prorocentrum consutum sp. nov. (Dinophyceae), a new benthic 467 dinoflagellate from South Brittany (northwestern France). Journal of Phycology 46(1): 468 183-194. 

bimaculatum sp. nov. (Dinophyceae, Prorocentrales), a new benthic dinoflagellate species from Kuwait (Arabian Gulf). Journal of Phycology 48(1): 211-221.

Chomérat, N., Zentz, F., Boulben, S., Bilien, G., van Wormhoudt, A., Nézan, E. 473 (2011). Prorocentrum glenanicum sp. nov. and P. pseudopanamense sp. nov.

474 (Prorocentrales, Dinophyceae), two new benthic dinoflagellate species from South 475 Brittany (northwestern France). Phycologia 50(2): 202-214.

476 CouTÉ, A. (2002). Biologie et microscopie électronique à balayage. Mémoires de la 477 Société Entomologique de France 6: 31-44.

478 Croome, R. L., HallegraefF, G. M., Tyler, P. A. (1987). Thecadiniopsis tasmanica 479 gen. et sp. nov. (Dinophyta: Thecadiniaceae) from Tasmanian waters. British $480 \quad$ Phycological Journal 22: 325-333.

481 DANEy DE MARCILlaC, S. (1846). Histoire de la Martinique depuis la colonisation 482 jusqu'en 1815. Tome 1er. E. Ruelle, Fort-Royal.

483 Delgado, G., Lechuga-Deveze, C. H., Popowski, G., Troccoli, L., Salinas, C. A. 484 (2006). Epiphytic dinoflagellates associated with ciguatera in the northwestern coast of 485 Cuba. Revista de Biologiá Tropical 54(2): 299-310.

486 Dragesco, J. (1965). Étude cytologique de quelques flagellés mésopsammiques.

487 Cahiers de Biologie Marine 6: 83-115.

488 DU TERTRE, J.-B. (1667-1671). Histoire générale des Antilles habitées par les François. 489 Tome II. T. Jolly, Paris. 
490 FAust, M. A. (1990). Morphologic details of six benthic species of Prorocentrum

491 (Pyrrhophyta) from a mangrove island, Twin Cays, Belize, including two new species.

492 Journal of Phycology 26: 548-558.

493 Faust, M. A. (1993a). Prorocentrum belizeanum, Prorocentrum elegans, and

494 Prorocentrum caribbaeum, three new benthic species (Dinophyceae), from a mangrove

495 island, Twin Cays, Belize. Journal of Phycology 29: 100-107.

496 FAUST, M. A. (1993b). Surface morphology of the marine dinoflagellate Sinophysis

497 microcephalus (Dinophyceae) from a mangrove island, Twin Cays, Belize. Journal of

498 Phycology 29: 355-363.

499 FAUST, M. A. (1993c). Three new benthic species of Prorocentrum (Dinophyceae) from

500 Twin Cays, Belize: P. maculosum sp. nov., $P$. foraminosum sp. nov. and $P$. formosum

501 sp. nov. Phycologia 32(6): 410-418.

502 Faust, M. A. (1994). Three new benthic species of Prorocentrum (Dinophyceae) from

503 Carrie Bow Cay, Belize: P. sabulosum sp. nov., $P$. sculptile sp. nov. and P. arenarium

504 sp. nov. Journal of Phycology 30: 755-763.

505 FAust, M. A. (1996). Dinoflagellates in a mangrove ecosystem, Twin Cays, Belize.

$506 \quad$ Nova Hedwigia 112: 447-460.

507 FAUST, M. A. (2009). Ciguatera-causing dinoflagellates in a coral-reef-mangrove

508 ecosystem, Belize. Atoll Research Bulletin 569: 1-30. 
509 FAust, M. A., BALECH, E. (1993). A further SEM study of marine benthic

510 dinoflagellates from a mangrove island, Twin Cays, Belize, including Plagiodinium

511 belizeanum gen. et sp. nov. Journal of Phycology 29: 826-832.

512 FAust, M. A., Gulledge, R. A. (2002). Identifying harmful marine dinoflagellates.

513 Smithsonian Institution. Contributions from the United States National Herbarium 42:

$514 \quad 1-144$.

515 FAust, M. A., Morton, S. L., QuOD, J.-P. (1996). Further SEM study of marine

516 dinoflagellates: the genus Ostreopsis (Dinophyceae). Journal of Phycology 32: 1053-

5171065.

518 Faust, M. A., Vandersea, M. W., Kibler, S. R., Tester, P. A., Litaker, R. W.

519 (2008). Prorocentrum levis, a new benthic species (Dinophyceae) from a mangrove

520 island, Twin Cays, Belize. Journal of Phycology 44: 232-240.

521 Fraga, S., Rodríguez, F., Caillaud, A., Diogène, J., Raho, N., ZaPata, M. (2011).

522 Gambierdiscus excentricus sp. nov. (Dinophyceae), a benthic toxic dinoflagellate from

523 the Canary Islands (NE Atlantic Ocean). Harmful Algae 11: 10-22.

524 FuKuYO, Y. (1981). Taxonomical study on benthic dinoflagellates collected in coral 525 reefs. Bulletin of the Japanese Society of Scientific Fisheries 47(8): 967-978.

526 Grzebyk, D., SAKo, Y., Berland, B. (1998). Phylogenetic analysis of nine species of

527 Prorocentrum (Dinophyceae) inferred from 18S ribosomal DNA sequences,

528 morphological comparisons, and description of Prorocentrum panamensis, sp. nov.

529 Journal of Phycology 34: 1055-1068. 
530 Grzebyk, D., Berland, B., Thomassin, B. A., Bosi, C., ArnouX, A. (1994). Ecology

531 of ciguateric dinoflagellates in the coral reef complex of Mayotte Island (S.W. Indian

532 Ocean). Journal of Experimental Marine Biology and Ecology 178: 51-66.

533 Guillard, R. R. L., RYTHER, J. H. (1962). Studies of marine planktonic diatoms. I.

534 Cyclotella nana Hustedt and Detonula confervacea Cleve. Canadian Journal of

535 Microbiology 8: 229-239.

536 Guindon, S., Dufayard, J.-F., Lefort, V., Anisimova, M., Hordijk, W., Gascuel,

537 O. (2010). New algorithms and methods to estimate Maximum-Likelihood phylogenies:

538 assessing the performance of PhyML 3.0. Systematic Biology 59(3): 307-321.

539 HERDMAN, E. C. (1921). Notes on dinoflagellates and other organisms causing

540 discolouration of the sand at Port Erin. Transactions of the Liverpool Biological Society

$541 \quad 35: 59-63$.

542 HERDMAN, E. C. (1922). Notes on dinoflagellates and other organisms causing

543 discolouration of the sand at Port Erin. II. Transactions of the Liverpool Biological

544 Society 36: 15-30.

545 HERDMAN, E. C. (1924a). Notes on dinoflagellates and other organisms causing

546 discolouration of the sand at Port Erin. III. Transactions of the Liverpool Biological

547 Society 38: 58-64.

548 HeRdman, E. C. (1924b). Notes on dinoflagellates and other organisms causing

549 discolouration of the sand at Port Erin. IV. Transactions of the Liverpool Biological

$550 \quad$ Society 38: $75-84$. 

dinoflagelados del género Gambierdiscus (Dinophyceae) del Mar Caribe mexicano. Revista de Biologiá Tropical 52(Suppl. 1): 77-87.

HoPPENRATH, M. (2000a). Morphology and taxonomy of the marine sand-dwelling genus Thecadinium (Dinophyceae), with the description of two new species from the

556 North German Wadden Sea. Phycologia 39: 96-108.

557 HOPPENRATH, M. (2000b). Taxonomische und ökologische Untersuchungen von

558 Flagellaten mariner Sande. University of Hamburg, Hamburg. 311 p.

559 HOPPENRATH, M., ElBRÄCHTER, M. (1998). Roscoffia capitata (Dinophyceae) refound:

560 notes on morphology and biology. Phycologia 37(6): 450-457.

561 Hoppenrath, M., Selina, M. (2006). Pseudothecadinium campbellii gen. nov. et sp.

562 nov. (Dinophyceae), a phototrophic, thecate, marine planktonic species found in the Sea

563 of Okhotsk, Russia. Phycologia 45(3): 260-269.

564 Hoppenrath, M., SAldarriaga, J. F., Schweikert, M., Elbrächter, M., TAYlor, F.

565 J. R. (2004). Description of Thecadinium mucosum sp. nov. (Dinophyceae), a new sand-

566 dwelling marine dinoflagellate, and an emended description of Thecadinium inclinatum

567 Balech. Journal of Phycology 40: 946-961.

568 Hoppenrath, M., Horiguchi, T., Miyoshi, Y., Selina, M., Taylor, F. J. R.,

569 LEANDER, B. S. (2007). Taxonomy, phylogeny, biogeography, and ecology of

570 Sabulodinium undulatum (Dinophyceae), including an emended description of the

$571 \quad$ species. Phycological research 55: 159-175. 
572 Hoppenrath, M., Chomérat, N., Horiguchi, T., Schweikert, M., Nagahama, Y.,

573 MurRay, S. (2013). Taxonomy and phylogeny of the benthic Prorocentrum species

574 (Dinophyceae) - a proposal and review. Harmful Algae 27: 1-28.

575 Hoppenrath, M., Bolch, C. J., Yoshimatsu, S.-A., SAldarriaga, J. F., Schweikert,

576 M., CAmpbell, C. N., Toriumi, S., Dodge, J. D., Elbrächter, M., TAYlor, D. L.

577 (2005). Nomenclatural note on a Thecadinium species (Dinophyceae, Gonyaulacales),

578 which was described as new independently three times within two months. Journal of

579 Phycology 41: 1284-1286.

580 HoriguCHI, T., CHIHARA, M. (1983). Stylodinium littorale, a new marine dinococcalean

581 alga (Pyrrhophyta). Phycologia 22: 23-28.

582 KATOH, K., STANDLEY, D. M. (2013). MAFFT multiple sequence alignment software

583 version 7: improvements in performance and usability. Molecular Biology and

584 Evolution 30(4): 772-780.

585 Keller, M. D., Selvin, R. C., Claus, W., Guillard, R. R. L. (1987). Media for the

586 culture of oceanic ultraphytoplankton. Journal of Phycology 23: 633-638.

587 LARSEN, J. (1985). Algal studies of the Danish Wadden Sea II. A taxonomic study of 588 psammobious dinoflagellates. Opera Botanica 79: 14-37.

589 Litaker, R. W., VAndersea, M. W., FAust, M. A., Kibler, S. R., NAU, A. W.,

590 Holland, W. C., Chinain, M., Holmes, M. J., Tester, P. A. (2010). Global

591 distribution of ciguatera causing dinoflagellates in the genus Gambierdiscus. Toxicon $592 \quad$ 56(5): 711-730. 
593 McNeill, J., Barrie, F. R., Buck, W. R., Demoulin, V., Greuter, W.,

594 Hawksworth, D. L., Herendeen, P. S., Knapp, S., Marhold, K., Prado, J.,

595 Prud'homme Van Reine, W. F., Smith, G. F., Wiersema, J. H., Turland, N. J. (2012).

596 International Code of Nomenclature for algae, fungi and plants (Melbourne Code).

597 Regnum Vegetabile volume 154. Koeltz Scientific Books, Königstein.

598 MurRAY, S. (2009). Diversity and phylogenetics of sand-dwelling dinoflagellates.

599 VDM Verlag Dr. Müller, Saarbrücken, Germany.

600 Murray, S., Hoppenrath, M., Preisfeld, A., LARsen, J., Yoshimatsu, S.-A.,

601 TORIUMi, S., PATTERSOn, D. J. (2006). Phylogenetics of Rhinodinium broomeense gen.

602 et sp. nov., a peridinioid, sand dwelling dinoflagellate (Dinophyceae). Journal of

603 Phycology 42: 934-942.

604 Olsen, D. A., Nellis, D. W., Wood, R. S. (1984). Ciguatera in the Eastern Caribbean.

605 Marine Fisheries Reviews 46(1): 13-18.

606 PosADA, D. (2008). jModelTest: Phylogenetic model averaging. Molecular Biology and 607 Evolution 25(7): 1253-1256.

608 PotTIER, I., VernouX, J.-P., Lewis, R. J. (2001). Ciguatera fish poisoning in the

609 Caribbean islands and Western Atlantic. Reviews of Environmental Contamination and

610 Toxicology 168: 99-141.

611 RASBAND, W. S. (1997-2006). ImageJ. In, National Institutes of Health, Bethesda,

612 Maryland. 
613 Rodriguez, E. A., Mancera Pineda, J. E., Gavio, B. (2010). Survey of benthic

614 dinoflagellates associated to beds of Thalassia testudinum in San Andrés Island,

615 Seaflower Biosphere Reserve, Caribbean Colombia. Acta Biologica Colombiana 15(2):

$616 \quad 229-246$.

617 Ronquist, F., Huelsenbeck, J. P. (2003). MrBayes 3: Bayesian phylogenetic inference 618 under mixed models. Bioinformatics 19(12): 1572-1574.

619 Rosine, J., J.L., C., CARdoso, T., QuÉnel, P. (2008). La ciguatéra dans les Antilles

620 Françaises. In Premières journées interrégionales de Veille Sanitaire des Antilles 621 Guyane, Schoelcher, Martinique.

622 SAUNDERS, R. D., Dodge, J. D. (1984). An SEM study and taxonomic revision of some 623 armoured sand-dwelling marine dinoflagellates. Protistologica 20(2): 271-283.

624 Tamura, K., Peterson, D., Peterson, N., Stecher, G., Nei, M., Kumar, S. (2011).

625 MEGA5: Molecular Evolutionary Genetics Analysis using Maximum Likelihood, 626 evolutionary distance, and Maximum Parsimony methods. Molecular Biology and 627 Evolution 28(10): 2731-2739.

628 Tamura, M., Horiguchi, T. (2005). Pileidinium ciceropse gen. et sp. nov.

629 (Dinophyceae), a sand-dwelling dinoflagellate from Palau. European Journal of 630 Phycology 40(3): 281-291.

631 TAYLOR, F. J. R. (1979). A description of the benthic dinoflagellate associated with 632 maitotoxin and ciguatoxin, including observations on Hawaiian material. In Toxic 633 dinoflagellate blooms (D. L. TAYLOR, H. H. SELIGER editors), pp. 71-76. Elsevier North 634 Holland, New York. 
635 TAYLOR, F. J. R. (1985). The distribution of the dinoflagellate Gambierdiscus toxicus in

636 the eastern Caribbean. In Proc. Fifth International Coral Reef Congress (C. GABRIÉ, B.

637 SAlVAT editors), pp. 423-428. MNHN-EPHE, Moorea, Tahiti.

638 Tester, P. A., Feldman, R. L., NaU, A. W., Kibler, S. R., Wayne Litaker, R.

639 (2010). Ciguatera fish poisoning and sea surface temperatures in the Caribbean Sea and 640 the West Indies. Toxicon 56(5): 698-710.

641 Tosteson, T. R. (2004). Caribbean ciguatera: a changing paradigm. Revista de Biologiá 642 Tropical 52(1): 109-113.

643 Vernoux, J.-P. (1988). La ciguatera dans l'île de Saint-Barthélémy : aspects

644 épidémiologiques, toxicologiques et préventifs. Oceanologica acta 11(1): 37-46.

645 Yamada, N., Terada, R., TANAKA, A., Horiguchi, T. (2013). Bispinodinium

646 angelaceum gen. et sp. nov. (Dinophyceae), a new sand-dwelling dinoflagellate from

647 the seafloor off Mageshima Island, Japan. Journal of Phycology 49: 555-569.

648 Yoshimatsu, S.-A., Toriumi, S., Dodge, J. D. (2004). Morphology and taxonomy of

649 five marine sand-dwelling Thecadinium species (Dinophyceae) from Japan, including

650 four new species : Thecadinium arenarium sp. nov., Thecadinium ovatum sp. nov.,

651 Thecadinium striatum sp. nov. and Thecadinium yashimaense sp. nov. Phycological

652 research 52: 211-223.

653 
654 Figure legends:

655

656 Fig. 1. Maps showing the localization of the Martinique Island in the Caribbean Sea

657 (Atlantic Ocean), and the sampling area (Anse Dufour) on the western coast of the 658 island.

659

660 Figs 2-10. Light micrographs of Madanidinium loirii gen. et sp. nov. 2. Right lateral

661 view of a living cell with the longitudinal flagellum (lf) visible. 3. Left lateral view of a

662 living cell with a pusule (pu) visible. 4. Dorsal view of a living cell showing the

663 epitheca inclined toward the right side. 5. Right view of a cell with focus on the nucleus

664 (n). 6. Right lateral view of a fixed environmental specimen used for single-cell

665 molecular analysis (isolate IFR 12-200). 7. Left lateral view of a DAPI-stained

666 specimen showing the posterior position of the nucleus (n). 8. Right lateral view of a

667 living cell seen in epifluorescence (blue excitation) showing chlorophyll

668 autofluorescence and the presence of small discoid chloroplasts. 9-10. Detail of sulcal

669 plates of two specimens stained with Calcofluor white. Except in Fig. 6, all specimens

670 are from strain IFR-MLO-02M. Scale bars: $10 \mu \mathrm{m}$.

671

672 Figs 11-15. SEM micrographs of Madanidinium loirii gen. et sp. nov. from strain IFR-

673 MLO-02M. 11. Right lateral view (holotype specimen). 12. Left lateral view, note the

674 reduced epitheca and area of densely arranged pores (arrowhead). 13. Ventral view

675 showing the tilted epitheca. 14. Dorso-lateral view (arrowhead pointing to the area of

676 densely arranged pores). 15. Antapical view. Scale bars: $10 \mu \mathrm{m}$.

677 
678 Figs 16-23. Details of the theca of Madanidinium loirii gen. et sp. nov. in SEM. 16.

679 Apical view. 17. Right lateral side of the epitheca. 18. Left lateral side of the epitheca.

680 19. Ventral view of the epitheca, note the flagellar pore (fp) visible partially. 20. Dorsal

681 view. 21. Detail of thecal surface with groups of pores and some isolated pores. 22.

682 Oval area of densely arranged pores on the $2^{\prime \prime \prime}$ plate. 23. Area of pores on the 2 "' plate

683 of another specimen, note that the shape is elongated. Scale bars: $5 \mu \mathrm{m}$ in Figs 16-20; 1 $684 \mu \mathrm{m}$ in Figs 21-23.

685

686 Figs 24-28. Line drawings of Madanidinium loirii gen. et sp. nov. 24. Representation of 687 a live cell in right lateral view (n: nucleus, pu: pusule). 25. Ventral view of the theca.

688 26. Apical view. 27. Right lateral view. 28. Left lateral view. Scale bars: $10 \mu \mathrm{m}$ in Figs.

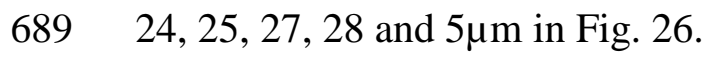

690

691 Fig. 29 Maximum likelihood (ML) phylogenetic tree inferred from SSU rDNA (matrix 692 of 77 taxa and 1691 aligned positions). The tree was rooted using Perkinsus marinus 693 sequence as outgroup. Model selected GTR $+\mathrm{I}+\Gamma_{4} . \log$ likelihood $=-19792.7$.

694 Substitution rate matrix: $\mathrm{A} \leftrightarrow \mathrm{C}=1.52090, \mathrm{~A} \leftrightarrow \mathrm{G}=4.15185, \mathrm{~A} \leftrightarrow \mathrm{T}=1.43273, \mathrm{C} \leftrightarrow$ $695 \mathrm{G}=0.81766, \mathrm{C} \leftrightarrow \mathrm{T}=9.38294$, against $\mathrm{G} \leftrightarrow \mathrm{T}=1.00000$. Assumed nucleotide 696 frequencies: $\mathrm{f}(\mathrm{A})=0.24690, \mathrm{f}(\mathrm{C})=0.19272, \mathrm{f}(\mathrm{G})=0.25795, \mathrm{f}(\mathrm{T})=0.30243$. Among site 697 rate variation: assumed proportion of invariable sites $I=0.317$. Rates at variable site 698 assumed to be gamma distributed with shape parameter $\alpha=0.511$. Bootstrap values 699 (1,000 pseudoreplicates) $>65$ (in ML) and posterior probabilities $>0.5$ (in BI) are 700 shown at nodes, thick lines indicate full support of the branch (100/1.00). '+' indicate 
nodes present but unsupported. Asterisks indicate benthic taxa with a lateral compression related to $M$. loirii by morphology.

703

704 Fig. 30 Maximum likelihood (ML) phylogenetic tree inferred from partial LSU rDNA

705 (matrix of 49 taxa and 860 aligned positions). The tree was rooted using Perkinsus

706 marinus sequence as outgroup. Model selected TN93 $+\Gamma_{4} \cdot \log$ likelihood $=$

$707-14250.35343$. Transition/transversion ratio for purines $=2.860 ;$ transition/transversion

708 ratio for pyrimidines $=7.812$. Nucleotides frequencies $\mathrm{f}(\mathrm{A})=0.23690, \mathrm{f}(\mathrm{C})=0.18977$,

$709 \mathrm{f}(\mathrm{G})=0.28854, \mathrm{f}(\mathrm{T})=0.28479$. Rates at variable site assumed to be gamma distributed

710 with shape parameter $\alpha=0.528$. Only bootstrap values $(1,000$ pseudoreplicates $)>65$

711 (in ML) and posterior probabilities > 0.5 (in BI) are shown at nodes; thick lines indicate

712 full support of the branch (100/1.00); '+' indicates a node present but unsupported and

713 '-' indicates an irresolution (in BI). Benthic taxa with a lateral compression are

714 highlighted with asterisks. 


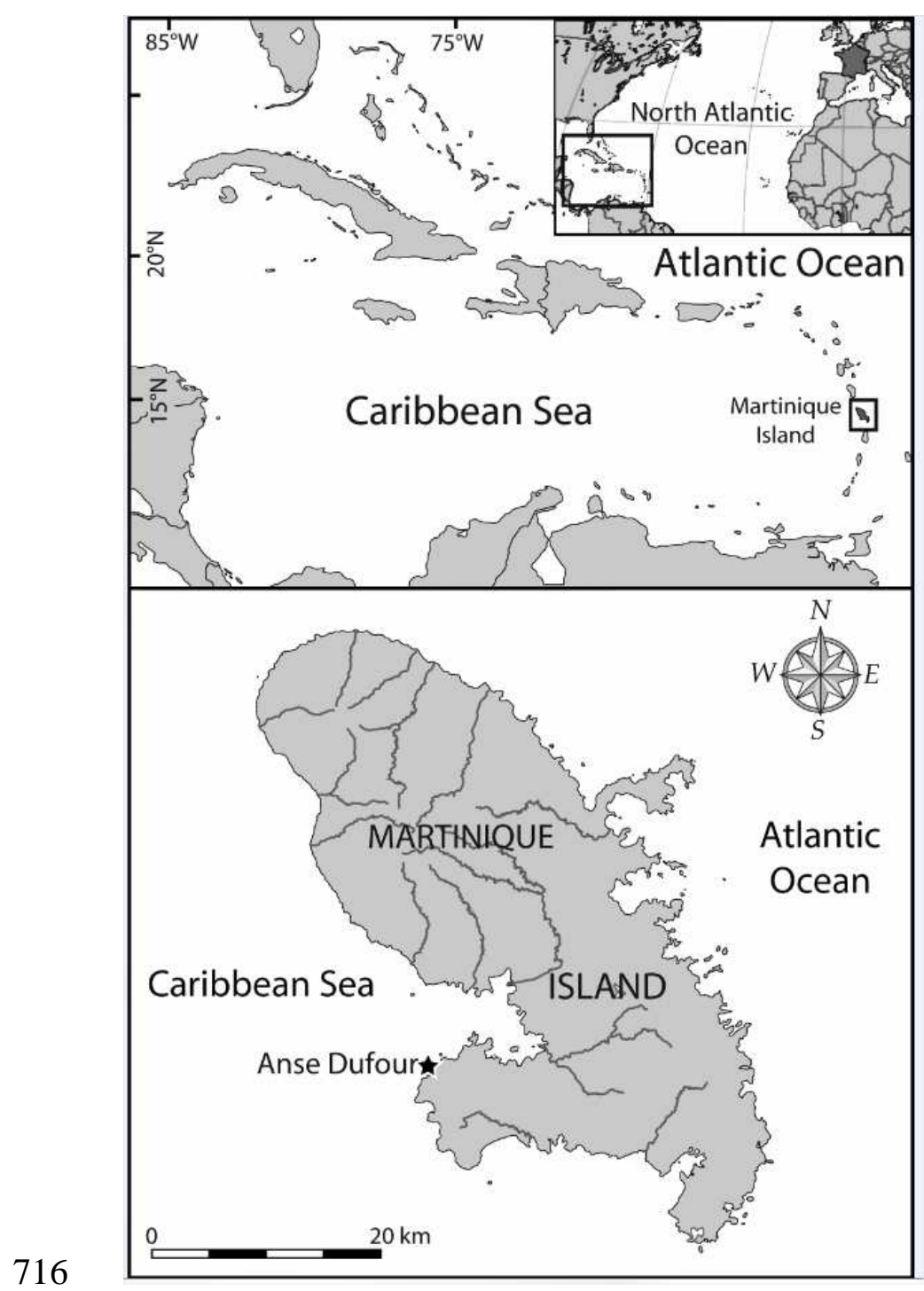

$717 \quad$ Fig. 1 


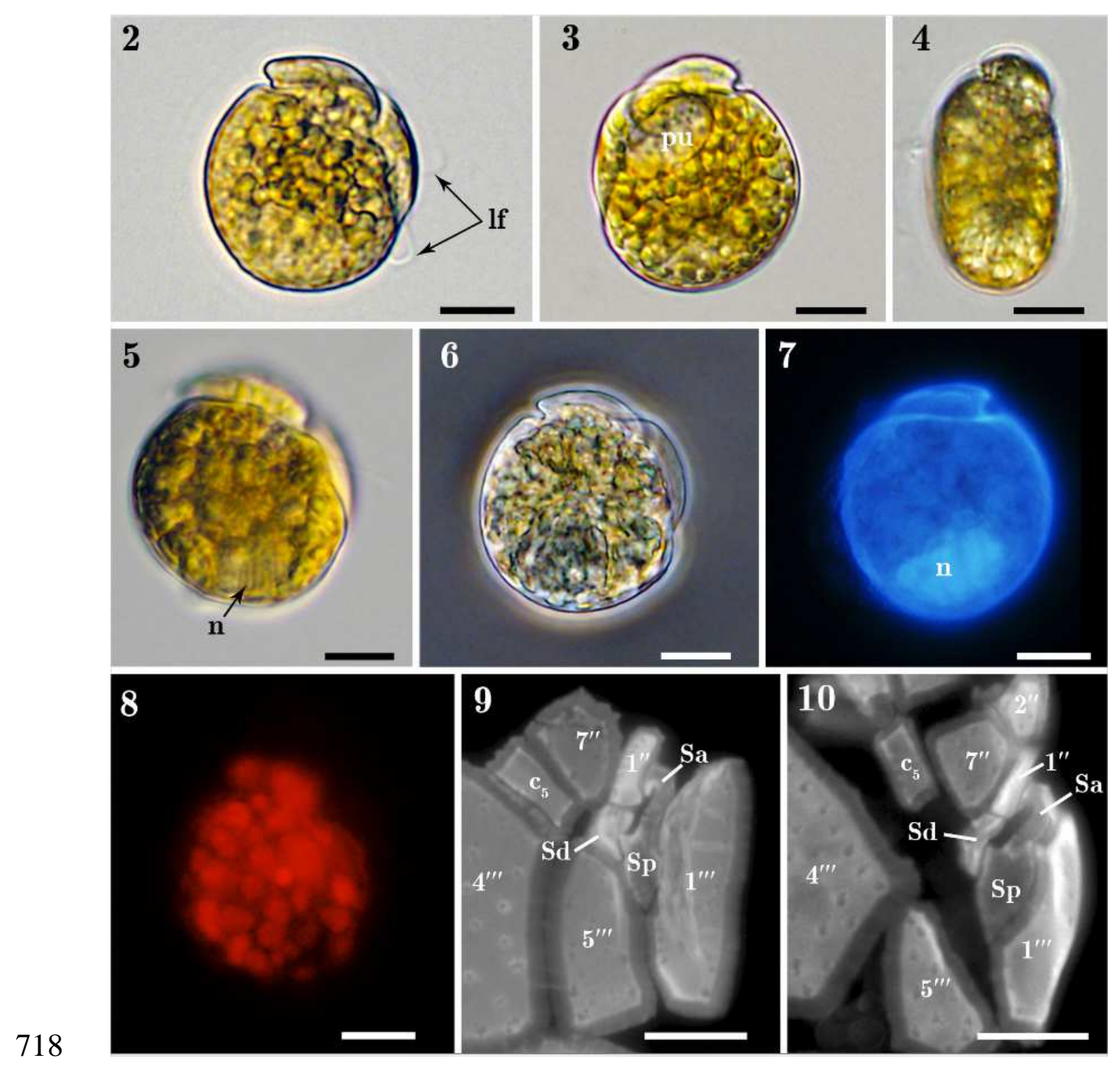

719 


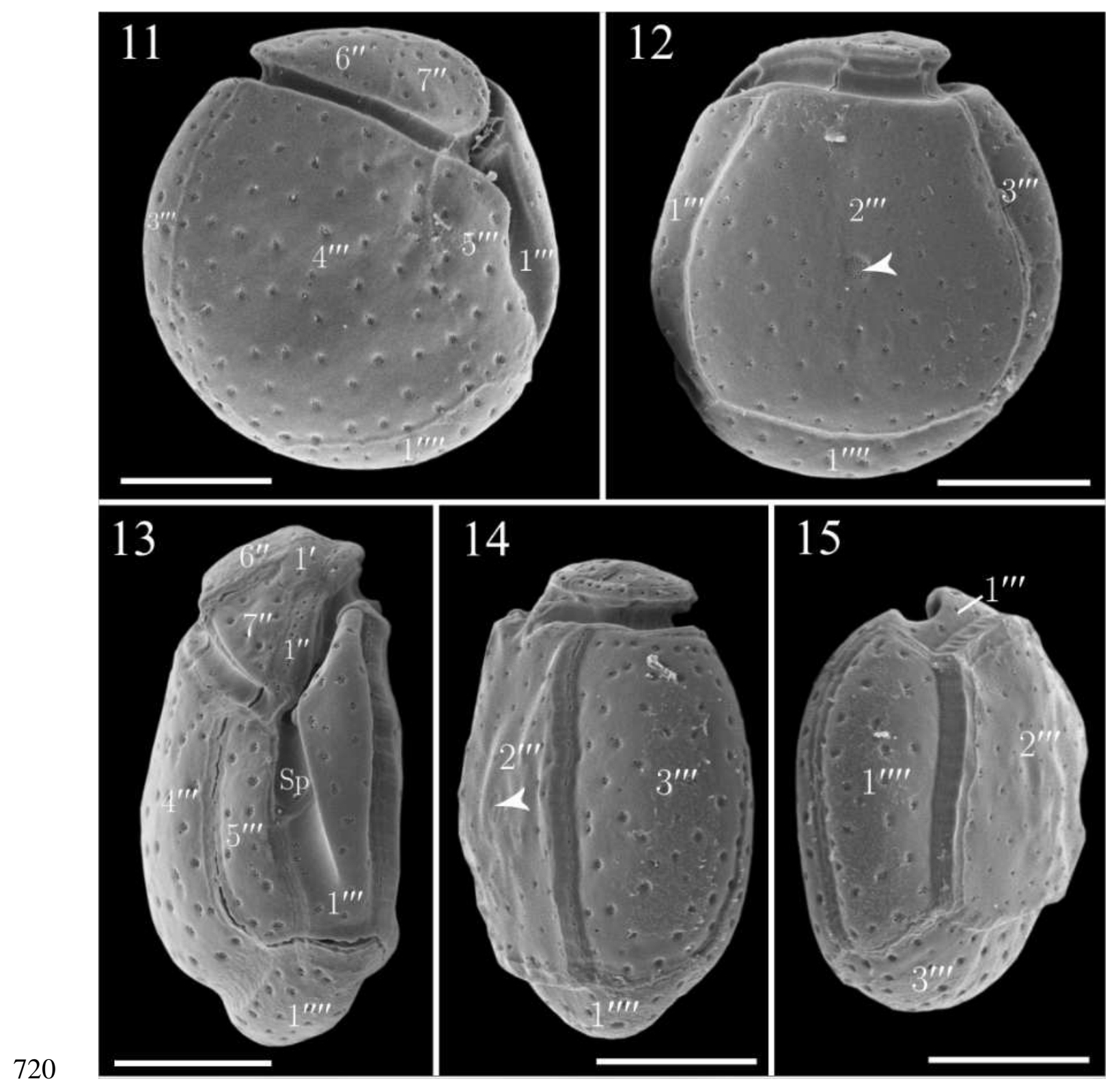




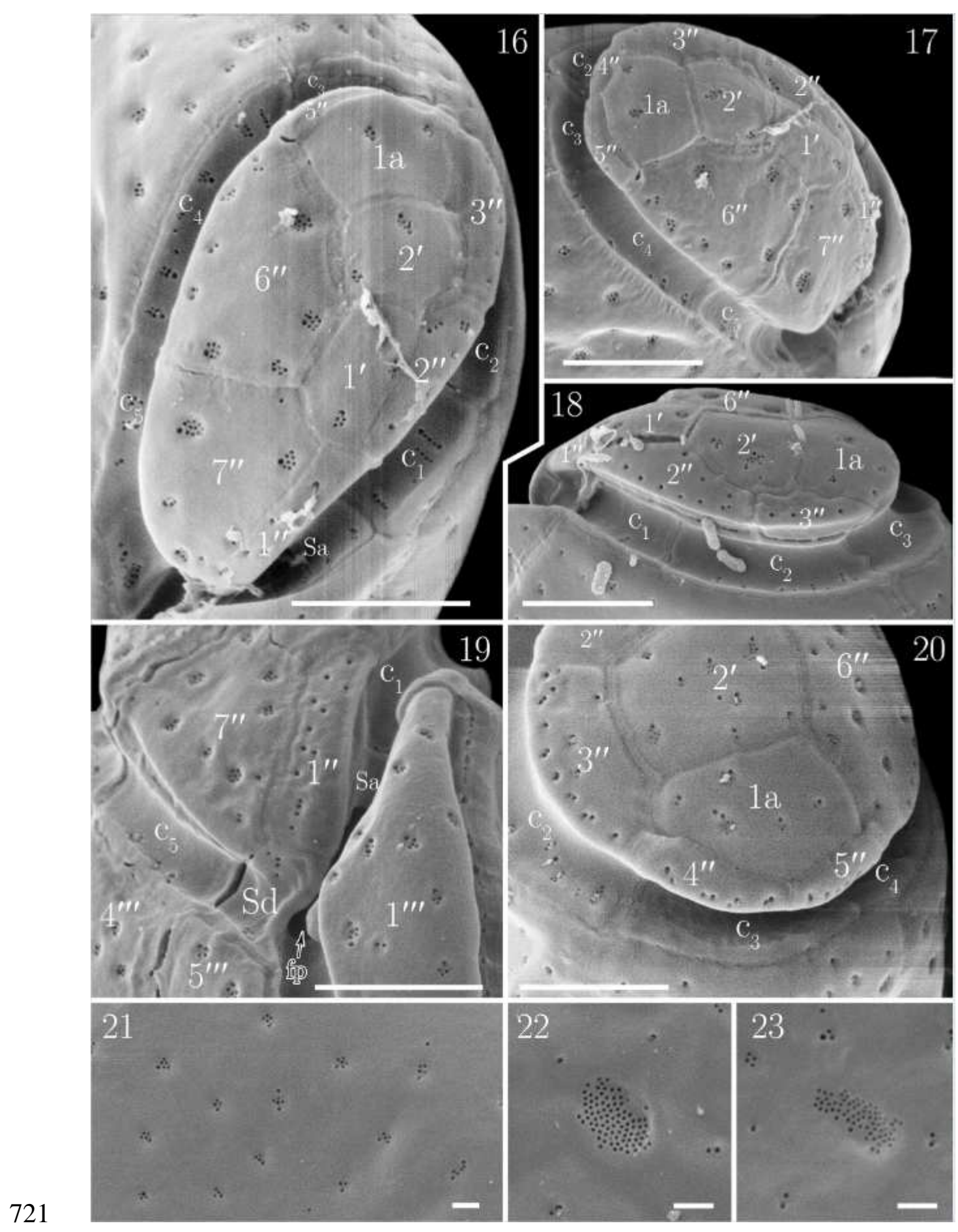




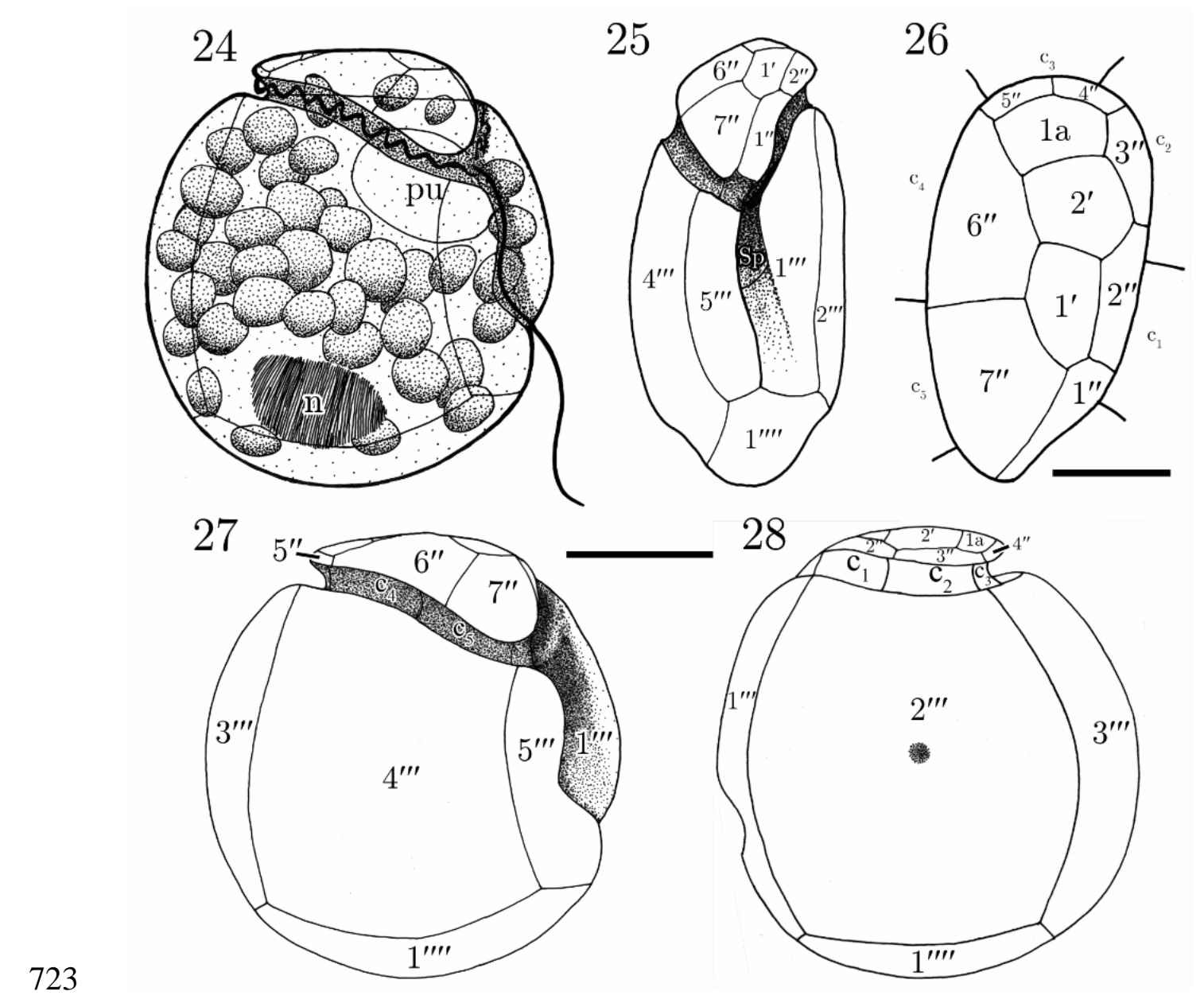

724 


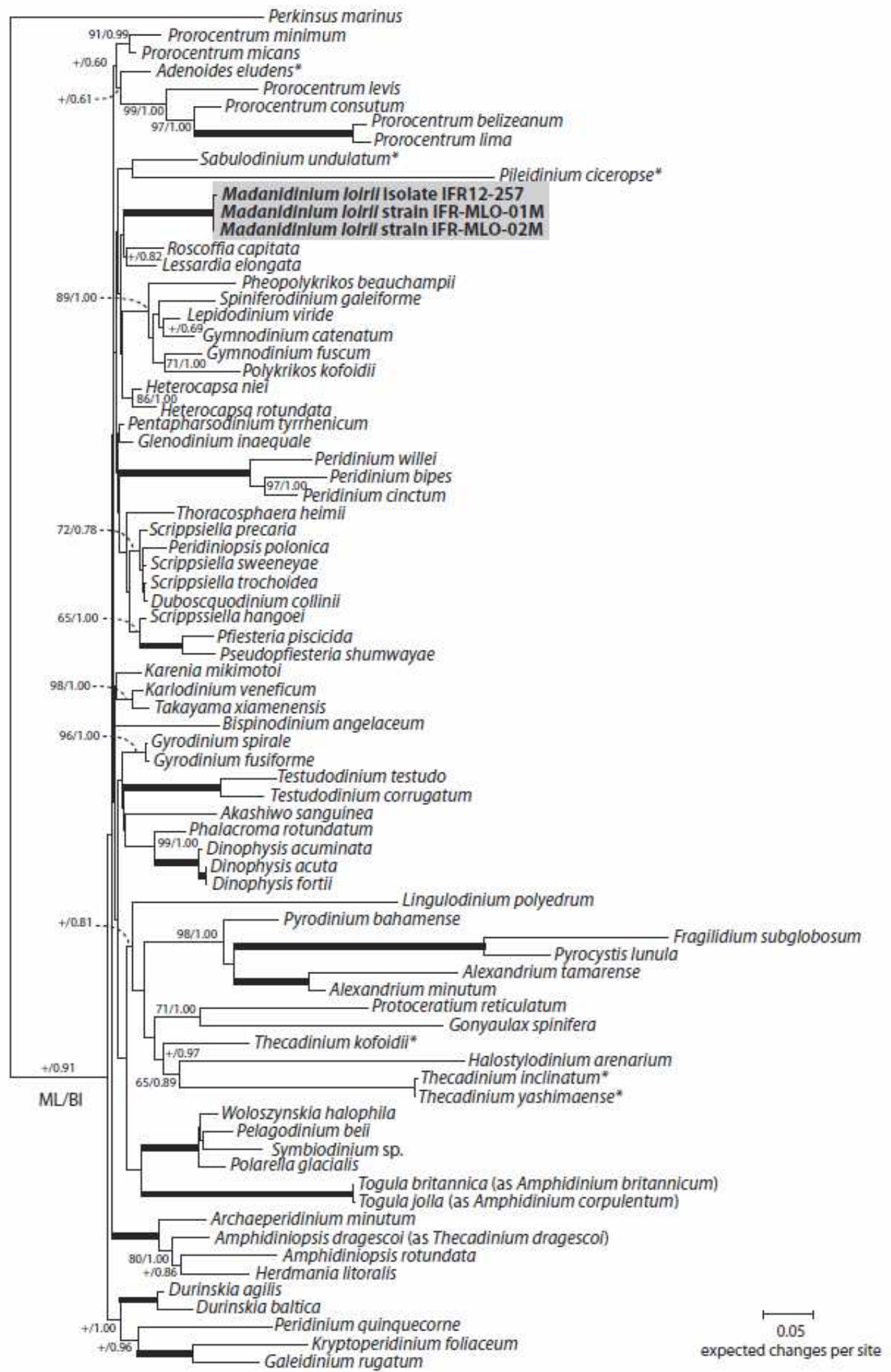

$727 \quad$ Fig. 29 


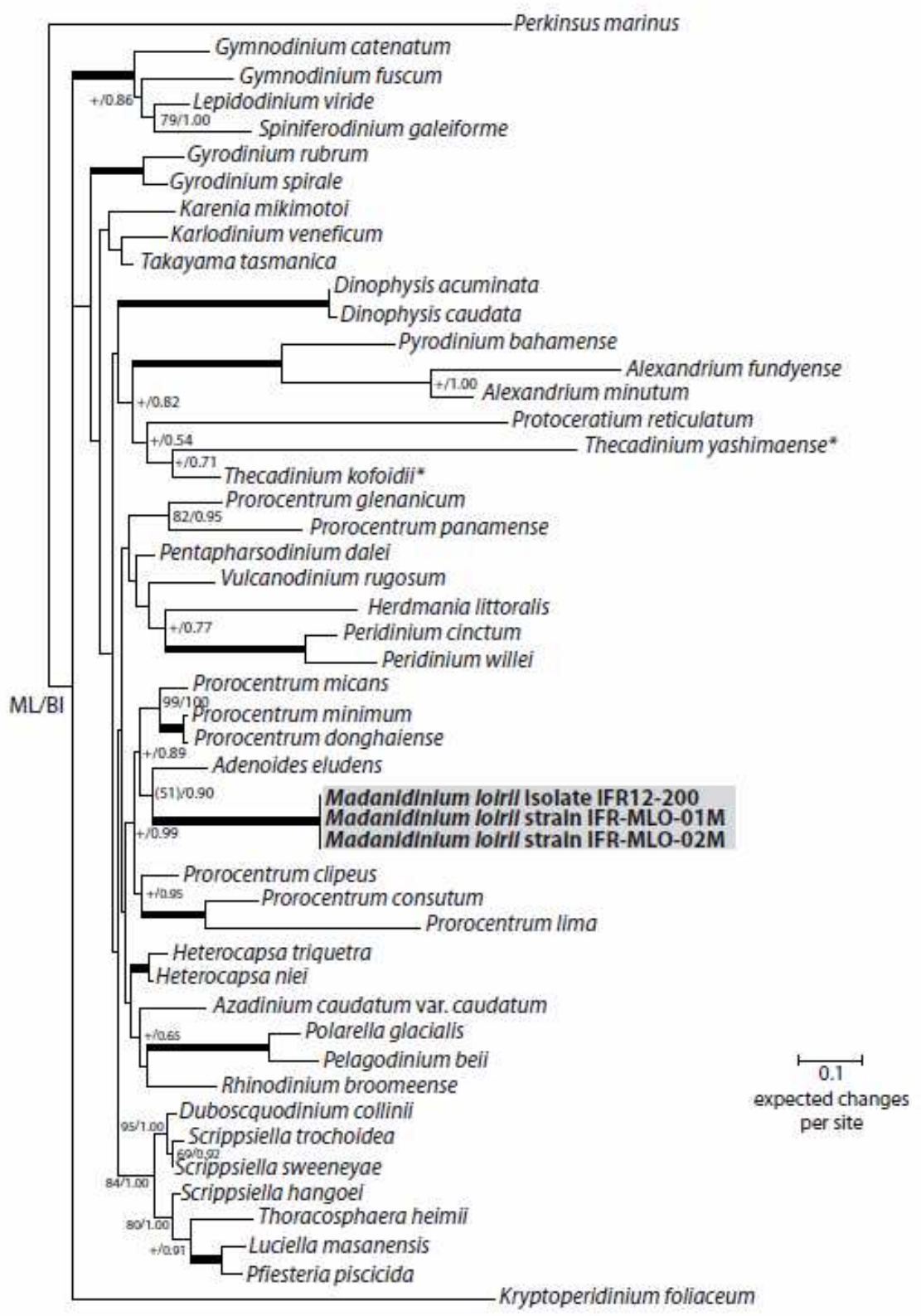

$729 \quad$ Fig. 30 
Table 1: Comparative features of Madanidinium loirii and other selected sand-dwelling dinoflagellate genera with a laterally-compressed body

(Thecadinium excluded), and the planktonic genera Thecadiniopsis and Pseudothecadinium.

\begin{tabular}{|c|c|c|c|c|c|c|}
\hline & $\begin{array}{l}\text { Madanidinium } \\
\text { gen. nov. } \\
\text { Chomérat }^{1}\end{array}$ & $\begin{array}{l}\text { Cabra } \\
\text { Murray et Patterson } \\
\text { emend. Chomérat et al. }{ }^{2,3}\end{array}$ & $\begin{array}{l}\text { Planodinium } \\
\text { Saunders et } \\
\text { Dodge }^{4}\end{array}$ & $\begin{array}{l}\text { Plagiodinium } \\
\text { Faust et } \\
\text { Balech }^{5}\end{array}$ & $\begin{array}{l}\text { Sabulodinium } \\
\text { Saunders et } \\
\text { Dodge }^{4,6}\end{array}$ & $\begin{array}{l}\text { Pileidinium } \\
\text { Tamura et } \\
\text { Horiguchi }^{7}\end{array}$ \\
\hline $\begin{array}{l}\text { shape (in lateral } \\
\text { view) }\end{array}$ & $\begin{array}{l}\text { roughly } \\
\text { circular }\end{array}$ & polygonal & $\begin{array}{c}\text { roughly } \\
\text { quadrangular }\end{array}$ & oblong & $\begin{array}{c}\text { more or less } \\
\text { oval }\end{array}$ & trapezoidal \\
\hline $\begin{array}{l}\text { cingulum } \\
\text { apical pore }\end{array}$ & $\begin{array}{c}\text { descending } \\
\text { absent }\end{array}$ & $\begin{array}{l}\text { ascending } \\
\text { present, } \\
\text { APC }\end{array}$ & $\begin{array}{c}\text { not displaced } \\
\text { absent }\end{array}$ & $\begin{array}{c}\text { not displaced } \\
\text { present, } \\
\text { APC? }\end{array}$ & $\begin{array}{c}\text { not displaced } \\
\text { present, } \\
\text { APC }\end{array}$ & $\begin{array}{c}\text { incomplete } \\
\text { present, } \\
\text { simple }\end{array}$ \\
\hline apical plates (') & 2 & 3 & 3 & 5 & 5 & 1 \\
\hline $\begin{array}{l}\text { anterior intercalary } \\
\text { (a) }\end{array}$ & 1 & 1 & 0 & 0 & 1 & 0 \\
\hline $\begin{array}{l}\text { precingular plates } \\
\left({ }^{\prime \prime}\right)\end{array}$ & 7 & 5 & 7 & 0 & 6 & 5 \\
\hline cingular plates (c) & 5 & 3 & 6 & 5 & 5 & 4 \\
\hline sulcal plates (s) & 3 & $?$ & $?$ & 5 & 4 & 4 \\
\hline $\begin{array}{l}\text { postcingular plates } \\
\left({ }^{\prime \prime \prime}\right)\end{array}$ & 5 & 5 & 3 & 5 & 5 & 5 \\
\hline antapical plates & 1 & 1 & 1 & 1 & 1 & 1 \\
\hline
\end{tabular}




\begin{tabular}{|c|c|c|c|c|c|c|}
\hline \multicolumn{7}{|l|}{$\operatorname{size}(\mu \mathrm{m})$} \\
\hline length & $25-31$ & $32-51$ & $27-30$ & $26-31$ & $27-43$ & $14-26$ \\
\hline depth & $22-29$ & $23-43$ & - & $20-25^{* *}$ & $18-36$ & $14-20$ \\
\hline width & $16-19$ & $17^{*}$ & $10-11$ & $6-9^{* *}$ & - & $10-14$ \\
\hline \multicolumn{7}{|l|}{ ornamentation } \\
\hline plates & smooth & $\begin{array}{c}\text { foveate, reticulate or } \\
\text { areolate }\end{array}$ & $\begin{array}{l}\text { with ridges, } \\
\text { reticulate }\end{array}$ & smooth & smooth & reticulate \\
\hline thecal pores & $\begin{array}{l}\text { arranged in } \\
\text { small groups }\end{array}$ & scattered, two kinds & $\begin{array}{l}\text { surrounded by } \\
\text { smaller pores }\end{array}$ & $\begin{array}{l}\text { some small } \\
\text { pores }\end{array}$ & $\begin{array}{l}\text { simple, } \\
\text { scattered }\end{array}$ & not described \\
\hline $\begin{array}{l}\text { special area of } \\
\text { pores }\end{array}$ & $\begin{array}{l}\text { present, lateral } \\
\text { (on 2"' plate) }\end{array}$ & $\begin{array}{l}\text { present, antapical } \\
\text { (on } 1^{\prime \prime \prime \prime} \text { plate) }\end{array}$ & absent & absent & absent & absent \\
\hline nucleus & ovoid, posterior & $\begin{array}{l}\text { ovoid, } \\
\text { dorsal }\end{array}$ & $\begin{array}{l}\text { ovoid, } \\
\text { posterior }\end{array}$ & $\begin{array}{l}\text { spherical, } \\
\text { posterior }\end{array}$ & posterior & $\begin{array}{l}\text { ovoid, } \\
\text { posterior }\end{array}$ \\
\hline habitat & benthic, marine & $\begin{array}{l}\text { benthic, } \\
\text { marine }\end{array}$ & $\begin{array}{l}\text { benthic, } \\
\text { marine }\end{array}$ & $\begin{array}{l}\text { benthic, } \\
\text { marine }\end{array}$ & $\begin{array}{l}\text { benthic, } \\
\text { marine }\end{array}$ & $\begin{array}{l}\text { benthic, } \\
\text { marine }\end{array}$ \\
\hline trophic mode & phototrophic & heterotrophic & heterotrophic & phototrophic & heterotrophic & phototrophic \\
\hline
\end{tabular}


Table 1 (cont.)

\begin{tabular}{cc}
\hline \hline $\begin{array}{c}\text { Thecadiniopsis } \\
\text { Croome } \text { et al. }^{8}\end{array}$ & $\begin{array}{c}\text { Pseudothecadinium } \\
\text { Hoppenrath et Selina }\end{array}$ \\
\hline broadly ovoid \\
descending \\
present & ovoid \\
4 & strongly descending \\
1 & 4 \\
4 & 4 \\
5 & 4 \\
$5 ?$ & $5 ?$ \\
5 & 5 \\
1 & 1 \\
$42-48$ & $36-53$ \\
$25-30$ & $31-45$ \\
$36-41$ & - \\
smooth & scattered, large \\
scattered, large &
\end{tabular}




\begin{tabular}{cc} 
absent & absent \\
$?$ & ovoid, \\
& posterior \\
planktonic, & planktonic, \\
freshwater (coastal) & marine and brackish \\
phototrophic & phototrophic \\
\hline \hline
\end{tabular}

${ }^{1}$ present study; ${ }^{2}$ Murray \& Patterson (2004); ${ }^{3}$ Chomérat et al. (2010a); ${ }^{4}$ Saunders \& Dodge (1984); ${ }^{5}$ Faust \& Balech (1996); ${ }^{6}$ Hoppenrath et al. (2007); ${ }^{7}$ Tamura \& Horiguchi (2005); ${ }^{8}$ Croome et al. (1987); ${ }^{9}$ Hoppenrath and Selina (2006); ${ }^{*}$ measured only in C. matta; ${ }^{* *}$ depth and width values are reversed in Faust \& Balech (1993). 